\title{
Quarterdeck
}

Richard W. Spinrad, Editor

\section{SEPTEMBER 11, 2001}

Not to comment on the terrorist attacks of September 11, 2001 might be interpreted as some devaluation of the significance of these horrendous acts. On the other hand, this magazine is a testament to the objective and presumably politically non-controversial nature of oceanographic research; the reader might contend that terrorism and crimes against humanity have no relevance to the content of Oceanography. I'd like to believe that, but I also know that 20 years from now, when you, the reader, dig through your dusty old piles of magazines, and you come across this issue, the memories of the events of September 11th will still be strong, and your reaction is apt to be "wasn't the murder of some 5000 people important enough to merit some reference in this magazine?" I suppose the cynic would respond "yes, but only if these attacks had some relevance to the field of oceanography". I argue they do. Simply put, all of our lives have changed, and there will be an impact on our science. In the United States, for example, billions of dollars must be spent to rebuild and strengthen infrastructure, to compensate individuals and corporations for losses, and to establish new systems and processes for homeland security. It's a simple matter of fact that these resources will come from the same sources that support much of our oceanographic research. At sea, new precautions and safeguarding measures will need to be implemented to protect our ships and crews from potential threats that were previously deemed unlikely. Expect caution and risk tolerance to play a much larger role in definition of experimental sites, and research cruise tracks. The transnational nature of the buildup and execution of the acts of September 11 can only create discomfort (at least) and friction for some international activities... and most of our readers would agree that oceanography is inherently a global forum. And finally, while the death toll is, as yet, incomplete (as of this writing), we will ultimately learn that we have lost some wonderful and influential people from communities that impact our oceanographic world. A search of the business index for the World Trade Center, for example, lists nearly a dozen marine industrial corporations, and in Washington two young forecasters from the National/Naval Ice Center were killed in the Pentagon attack.

What should the oceanographic community do? I have no suggestions. I have no good ideas. I just believe these events cannot pass without comment.

OCEANOGRAPHY

wwwtosong

EDITOR

Richard W.Spirtad

U.S Naval Observatory

3450 Massachusetts Avenue, NW Washington, DC 20392-5421 USA (202) 762-1697 Fax: (202) 762-1025

spinrad richard@hq.navy.mil

ASSISTANT EDITOR

Elizabeth J. Tirpak

magazine@tos.org

ASSOCIATE EDITORS

Gregg J. Brunskill

Australian Institute of Marine Science PMB No. 3, Townsville, M.C. Queensland 4810, Australia

(61) 747534481 Fax: (61) 747725852 g.brunskill@aims.gov.au

Ellen R.M. Druffel Department of Earth System Science 222 Roland Hall University of California Irvine, California 92697-3100 USA

(949) 824-2116 Fax: (949) 824-3256 edruffel@uci.edu

Charles H. Greene

Director, Ocean Resources and Ecosystems Program Department of Earth \& Atmospheric Sciences

Cornell University

2130 Snee Hall

Ithaca, New York 14853-2701

(607) 255-5449 Fax: (607) 254-4780

chg2@cornell.edu

James Syvitski

Director, Institute of Arctic and Alpine Research University of Colorado at Boulder 1560 30th Street, Campus Box 450 Boulder, Colorado 80309-4050 USA (303) 492-7909 Fax (303) 492-6388 james.syvitski@colorado.edu

Peter Wadhams Scott Polar Research Institute University of Cambridge Lensfield Road

Cambridge CB2 1ER England +44 1223-336542

pw11@phx.cam.ac.uk

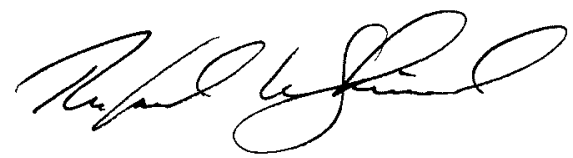

DESIGN/PRINTING

Corporate Press

403 Brightseat Road Landover, Maryland 20785 USA 